\title{
Salt intake in Ceylon
}

\author{
By K. MAHADEVA \\ Department of Pathology \\ AND E. KARUNANAYAKE \\ Department of Biochemistry, Bandaranaike Memorial Ayurvedic \\ Research Institute, Navinna, Ceylon
}

(Received 28 fanuary 1970-Accepted 24 March 1970)

\begin{abstract}
1. Salt is a convenient household commodity which is generally used as a vehicle for iodine in the prophylactic treatment of endemic goitre.

2. Iodization of salt depends on the normal requirements for iodine, the intensity of the environmental iodine deficiency, the presence of goitrogenic factors and the daily salt consumption per head of the population.

3. Although the intake of most nutrients has been worked out during the normal course of dietary surveys in the past, the daily salt consumption per head of the population has not been estimated.

4. In this survey a simple method has been described for evaluating salt consumption and this finding will be the basis for planning the iodization programme in Ceylon.
\end{abstract}

Several methods have been tried from time to time for providing supplementary iodine in the prophylaxis of endemic goitre. It is generally accepted that the most practical method is by the iodization of salt.

In deciding upon the level of iodization of salt to be adopted in any area, the following factors are taken into consideration: the normal requirements for iodine, the intensity of the environmental iodine deficiency, the presence of goitrogenic factors, and the daily consumption per head of the population (World Health Organization, 1960). The first three factors have been already dealt with in earlier papers (Mahadeva \& Senthe Shanmuganathan, 1967; Mahadeva, Seneviratne, Jayatilleke, Senthe Shanmuganathan, Premachandra \& Nagarajah, I968).

Although dietary surveys have been conducted in the past several years to determine the intake of nutrients in the food, no special effort has been made to estimate the intake of salt in Ceylon (Cullumbine, 1949; Gunasekera, 1958; Mahadeva \& de Silva, I962-3).

The salt used in Ceylon is the crude salt obtained by solar evaporation of salt water in salt pans situated in various parts of the country. In the kitchen the salt is generally dissolved, in order to separate the impurities, and decanted. The clear salt solution is then added to the food before cooking, and considerable wastage occurs.

In this study the amount of salt that goes into the preparation of food, expressed as $\mathrm{g} \mathrm{NaCl} /$ person per $\mathrm{d}$ was estimated by drying in the laboratory. 


\section{MATERIAL AND METHODS}

Several middle-class families were chosen for this investigation. The co-operation of the housewife was sought. The normal procedure of dissolving the salt and discarding impurities was not interrupted, but a measured amount of the clear salt solution added to the several dishes was collected in a separate empty bottle every day. These samples were collected over a period of ro $d$. The total number in the household was noted.

\section{RESULTS}

Eight families completed the ro d survey. The estimated intake was $7 \mathrm{~g} /$ person per $d$. Table I shows the number of persons in each family, the family make-up and the average individual intake of salt in $\mathrm{g} / \mathrm{d}$.

Table I. Consumption of salt (dry $\mathrm{NaCl}$ ) in eight households in Ceylon

$\begin{array}{cccc}\text { Name } & \text { Adults } & \begin{array}{c}\text { Children } \\ \text { under } \\ \text { I2 years }\end{array} & \begin{array}{c}\text { Consumption } \\ \text { of salt } \\ \text { (g/person d) }\end{array} \\ \text { Ma } & 6 & - & \text { ro.r } \\ \text { Go } & 9 & 4 & 7 \cdot 2 \\ \mathrm{Dh} & 3 & 3 & 5 \cdot 3 \\ \mathrm{Ka} & 7 & 3 & 8 \cdot 2 \\ \text { We } & 6 & 2 & 8 \cdot 6 \\ \mathrm{Su} & 5 & 4 & 3 \cdot 5 \\ \mathrm{Mo} & 6 & 1 & 7 \cdot 1 \\ \mathrm{Cy} & 6 & - & 5 \cdot 8\end{array}$

\section{DISCUSSION}

In this study we have estimated the daily salt consumption per head of the population. This finding will be the basis of planning the iodization programme in Ceylon.

In the East, the salt used for cooking is usually crude and contains a large amount of grit. If the vessel in which the salt is kept is exposed, as generally happens, extra impurities in the form of soot from open fireplaces are often introduced. The salt is dissolved and decanted to get rid of both the grit and soot, and the clear solution is added to the food before cooking. Considerable wastage occurs.

This investigation was carried out in households of educated people to ensure the co-operation of the housewives; it would not have been possible in the rural areas. Only eight families were able to give samples of the clear salt solution for a period of Io d. The mean individual consumption rate was $7 \mathrm{~g} /$ person per $\mathrm{d}$. Salt intake varies widely in different parts of the world (Table 2). In Indonesia, it is reported to be only 2 or $3 \mathrm{~g} / \mathrm{d}$; in West Africa (Nigeria) the intake is less than $7 \mathrm{~g} / \mathrm{d}$ (Ladell, 1957), whereas in Taiwan, in China, on an average, $10 \mathrm{~g}$ of crude salt are consumed daily (Kung-pei Chen, 1964). Western countries, e.g. the United States of America and the United Kingdom, quote figures of from 10 to $20 \mathrm{~g} / \mathrm{d}$ (Johnson, I95 I Black, 1952; Davidson $\&$ Passmore, 1967 ). The Indian estimate of salt consumption is in the range 
of from ${ }_{1} 5$ to $18 \mathrm{~g} / \mathrm{d}$ (Sooch $\&$ Ramalingaswami, I965; Pasricha, I966). These figures refer to crude salt. The authors have not stated whether the salt was cleaned before use.

WHO investigated iodine metabolism in endemic goitre in Ceylon and has recommended the provision of $100-150 \mu \mathrm{g}$ iodine/person per $\mathrm{d}$ for the control of endemic goitre (Subramanian \& Deo, r966). An earlier study of the iodine values of the different articles of food and the daily intake of iodine from foods in Ceylon show that the critical level below which goitre becomes endemic is $400 \mu \mathrm{g}$. The daily intake of iodine in the endemic area was in the range of $300-350 \mu \mathrm{g} / \mathrm{d}$ (uncorrected for cooking losses).

The amount of roo- $5^{\circ} \mu \mathrm{g}$ recommended by WHO, therefore, seems appropriate, as with this dosage it has been shown that complications such as iodism, Basedow's disease, iodine thyroiditis and goitre would not arise.

\section{Table 2. Salt consumption (g/person per $d$ ) in different countries}

\begin{tabular}{|c|c|c|c|c|}
\hline \multirow[b]{2}{*}{ Country } & \multirow{2}{*}{$\begin{array}{c}\text { No. of } \\
\text { families }\end{array}$} & \multicolumn{2}{|c|}{ Salt consumption } & \multirow[b]{2}{*}{ Reference } \\
\hline & & Mean value & Range & \\
\hline South India & 40 & 18 & $12-20$ & Pasricha (I966) \\
\hline North India & - & 15 & - & $\begin{array}{l}\text { Sooch \& Ramalingaswami } \\
\text { (1965) }\end{array}$ \\
\hline Taiwan & - & I0 & - & Kung-pei Chen (1964) \\
\hline USA & - & IO & - & Johnson (I95I) \\
\hline USA & - & Io & - & $\begin{array}{l}\text { United States Department } \\
\text { of Agriculture (1959) }\end{array}$ \\
\hline USA & - & 20 & - & Black (r952) \\
\hline UK & - & - & I $5-20$ & $\begin{array}{l}\text { Davidson \& Passmore } \\
(1967)\end{array}$ \\
\hline Indonesia & - & - & $2-3$ & Ladell (I957) \\
\hline $\begin{array}{l}\text { West Africa } \\
\text { (Nigeria) }\end{array}$ & - & 7 & - & Ladell (r957) \\
\hline Ceylon & 8 & 7 & $3 \cdot 5-10 \cdot 1$ & $\begin{array}{l}\text { Navinna Research Insti- } \\
\text { tute (present research) }\end{array}$ \\
\hline
\end{tabular}

Potassium iodate has been shown to be the compound of choice for iodization of salt (Sooch \& Ramalingaswami, I965). It is far more stable than the iodide, is less affected by oxidizing impurities and has a wide margin of safety. Further, the impurities and moisture in unrefined salt facilitate the breakdown of iodides which result in loss of iodine. Therefore it is advantageous to use refined salt for iodization and thus avoid cleaning and the loss of iodine. Using the mean value for salt consumption of $7 \mathrm{~g} / \mathrm{d}$, the appropriate level of iodine compound in salt would be $\mathrm{I}$ in 20000. Prophylaxis is a slow process but would afford protection to a population of about 7 million living in the endemic areas exposed to risk out of a total population of about 12 million in Ceylon.

There are several salterns in different parts of Ceylon. The possibility of making a concentrated preparation of potassium iodate at one centre and then diluting it at the other centres is exposed to risk. The Hambantota saltern, situated at the extreme end of the endemic area, could turn out iodized salt on a priority basis for the endemic area, as is done in India (Saidoff, r967; Sivasubramaniam, 1967). 
Prophylactic treatment by the use of iodized salt at an early date in the endemic area is recommended.

We are grateful to Mr Wimal Nawagamuwa, Commissioner for Ayurveda, for assistance in carrying out this investigation and permission to publish this paper.

\section{REFEREN CES}

Black, D. A. K. (1952). Sodium Metabolism in Health and Disease. Oxford: Blackwell Scientific Publications.

Cullumbine, H. (1949). Ceylon F. Sci. (D) 6, I.

Davidson, S. \& Passmore, R. (1967). Human Nutrition and Dietetics. Edinburgh and London: E. and S. Livingstone Ltd.

Gunasekera, D. B. (1958). Ceylon J. Sci.9, 107.

Johnson, D. (195I). Modern Dietetics. New York: G. P. Putnam and Sons.

Kung-pei Chen (1964). Second Far East Symposium on Nutrition p. 215. Taiwan, China: US Government Printing Office.

Ladell, W. S. S. (I957). Trans. R. Soc, trop. Med. Hyg. 51, I89.

Mahadeva, K. \& de Silva, W. A. B. (1962-3). 7. Ceylon publ. Hlth Ass. 3 and 4, 35.

Mahadeva, K., Seneviratne, D. A., Jayatilleke, D. B., Senthe Shanmuganathan, S., Premachandra, P. \& Nagarajah, M. (1968). Br. F. Nutr. 22, 527.

Mahadeva, K. \& Senthe Shanmuganathan, S. (1967). Br. Y. Nutr. 21, 34I.

Pasricha, S. (1966). F. Nutr. Dietet. 3, I.

Saidoff, I. (1967). Beaume' and Bittern-the Ceylon fournal of Salt 2, 17. Colombo, Ceylon: National Salt Corporation.

Sivasubramaniam, S. (1967). Beaume' and Bittern-the Ceylon fournal of Salt 2, 63. Colombo, Ceylon: National Salt Corporation.

Sooch, S. S. \& Ramalingaswami, V. (1965). Bull. Wld Hlth Org. 32, 229.

Subramanian, T. A. V. \& Deo, M. G. (1966). Assignment Report on Goitre Control, Ceylon, WHO Project: Ceylon 79. Regional office for South-East Asia.

United States Department of Agriculture (1959). 'Food'. Yb. U.S. Dep. Agric.

World Health Organization (1960). Monograph Ser. W.H.O. no. 44, p. 399. 